\title{
Postural Dysfunction in Stroke Rehabilitation
}

\section{Novitri Sumardi}

Department of Physical Medicine and Rehabilitation, Faculty of Medicine Universitas Padjadjaran, Dr. Hasan Sadikin General Hospital, Bandung Indonesia Bandung, Indonesia

\begin{abstract}
Introduction: Trunk control ia a major part of postural control during human movement. This are commonly affected in stroke but mostly are being overlooked compared to limb impairment. This article objective is to review the current literature on postural dysfunction after stroke and rehabilitation principles implementation.

Method: Literature or data sources comprised through computer-aided search of published papers with the key words of stroke or cerebrovascular accident, normal and pathological postural control, core stabilization exercise and trunk rehabilitation.

Result: Thirty five papers were selected and were published from 2010-2020.

Conclusion: The abdominal muscles are held responsible to form a muscular corset at the lumbar spine as proximal stabilization during any purposeful task. In stroke patients, the recruitment of postural control muscles is delayed with regard to the limbs activations. This will hamper the activities of daily living by disrupting the human postural adjustment mechanisms. The rehabilitation processes to regain postural control are vital, and should involve exercises to improve trunk "core" muscle stability.
\end{abstract}

Keywords: core stabilization, exercise, postural control, rehabilitation, stroke 


\begin{abstract}
ABSTRAK
Pendahuluan: Kontrol togok merupakan bagian utama kontrol postur tubuh saat manusia bergerak. Penyakit stroke memberikan dampak buruk nyata bagi kontrol ini yang seringkali terlewatkan di sebagian besar kasus. Tujuan penulisan artikel ini adalah untuk melakukan tinjauan terhadap berbagai literatur mengenai disfungsi postural pada penderita stroke dan penerapannya pada prinsip-prinsip rehabilitasi.

Metode: Literatur atau sumber data yang digunakan berasal dari pencarian artikel yang telah diterbitkan secara online, dengan kata kunci stroke atau serebrovaskular accident, kontrol postur normal dan patologis, latihan stabilisasi otot-otot inti tubuh dan rehabilitasi togok.

Hasil: Tiga puluh lima makalah terpilih yang diterbitkan dari tahun 2010-2020.

Diskusi: Otot-otot abdomen bekerja membentuk sebuah "korset otot" di area lumbalis yang berfungsi sebagai sebuah stabilisasi proksimal selama berlangsungnya berbagai aktivitas bertujuan. Pada pasien stroke, perekrutan otot kontrol postural terjadi secara terlambat bila dibandingkan proses perekrutan otot anggota gerak. Hal ini akan menghambat aktivitas kehidupan sehari-hari dengan cara mempengaruhi mekanisme penyesuaian postur tubuh manusia. Proses rehabilitasi untuk mendapatkan kembali kendali postural sangat penting, dan karenanya perlu melibatkan latihan peningkatan stabilitas otot-otot inti tubuh.
\end{abstract}

Kata kunci: kontrol postur, latihan fisik, rehabilitasi, stabilisasi otot inti tubuh, stroke.

\section{Correspondent Detail:}

\section{Novitri Sumardi}

E-mail : novitris@gmail.com

Department of Physical Medicine and

Rehabilitation, Faculty of Medicine

Universitas Padjadjaran, Dr. Hasan Sadikin

General Hospital, Bandung Indonesia

\section{INTRODUCTION}

Strokes are among the top three leading cause of disability worldwide1. Stroke by definition is the sudden occurrence of permanent damage to an area of the brain caused by a blocked blood vessel or bleeding within the brain. 2 To date, low- and middle-income country still has the highest stroke population with the rate up to $70 \%$ of strokes and $87 \%$ of both stroke-related deaths and disability-adjusted life years. ${ }^{1}$ The global lifetime risk of stroke is approximately $25 \%$ starting at the age of 25 years between both male and female population, with large variation of geographic that showed a particularly high lifetime risk of stroke in East Asia, Eastern Europe, and Central Europe. $^{3}$

In Indonesia, data from Riset Kesehatan Dasar - Ministry of Health Republic of Indonesia in 2018 shows that stroke prevalence is increased from 7\%o in 2013 to $10,9 \%$ in 2018. In West Java Provence, the stroke prevalence is a slightly higher comparing to national prevalence which is $11,4 \%{ }^{4}$ Stroke contributed either in high 
mortality and morbidity rate and among 50\% of survivors are being chronically disabled. ${ }^{5}$

For someone experiences a stroke event, a large number of physical dysfunction are followed. This will lead the patient to seek medical help to improve their quality of life (QoL).

When it comes to rehabilitation programs to achieve goals of QoL, most clinicians often focus only to dysfunction of the upper and lower limbs, or the changes in gait pattern. But nonetheless, there is part of human body who will also secretly suffer from stroke as well. Such part is the trunk which also takes an important aspect in determining the functional prognosis of stroke patients. The aim of this article is to review the current literature on the topic of postural dysfunction after stroke and what rehabilitation principles should be implemented during the process especially the concern of "core" muscle stabilization.

\section{METHOD}

The selection of literature or data matching to the topic was conducted through specific keywords using computer-aided search engine. The literature or data consist of eBooks, articles, or journals are not limited from any country or area in the world. The year of publication of the literature or data should not exceed more than ten years prior. Additional information sources which needed to clarify the main literature or data are obtained from the reference section of the papers. The inclusion criteria for literature or data used was base on the content which explains of trunk function physiology, the impact to it after having a stroke and the main principles in the rehabilitation processes.

\section{RESULT}

Thirty five papers were used to investigate the postural dysfunction after stroke. Nine of these were explained about the basis of functional postural control in accordance to limb movement with or without additional supporting examination such as electromyography or ultrasound imaging. Two of these nine papers were emphasized on anticipatory and compensatory postural adjustment during movement. The stroke impact on postural control was explored in the remaining 21 papers with principles and rehabilitation programs explored.

\section{DISCUSSION}

When dealing with human motion, we have to always keep in mind that trunk serves as a basis or the center of all movement. Trunk works as a proximal stabilizer when we are trying to accomplish the needed tasks of daily living. During activities like reaching or walking, the trunk muscles are quietly contracting to maintain posture. Anytime the body is upright, and especially when the limbs are active, the trunk muscles are engaged. The higher the intensity of the movement, the more trunk muscle is being switch on. Through the many complex systems in the human body, trunk stability is maintained for an infinite combination of limb movements. ${ }^{6,7}$

The documentation of trunk action while the limb was working has been investigated and recorded using neurophysiologic examination. The findings of one study noted the electromyogram effect in specific trunk musculature after adding hip movement into bridging exercise. ${ }^{8}$ Another recent 
study also found increased of the trunk muscles activity in stroke patients while performing bridging exercises with enclosing non-paretic arm flexion and horizontal abduction. ${ }^{9}$

The recent study by Zheng $\mathrm{Y}$ et al even combined between two standard measurements which is surface electromyographic (sEMG) and rehabilitative ultrasound image (RUSI) in local core muscle of healthy people. Both measurements are used as it was obtained that there is some inaccuracy in recording activity of the deep muscle fiber such as transversus abdominis or multifidus muscle, so rehabilitative ultrasound image as a recent method also implemented to assess muscle activation without invasive procedures. The intervention prescribed to all participants was core stabilization exercise program whilst raising and moving upper and lower limbs to give a more challenging task. The result of this study shown that the core muscle value of thickness contraction ratio and integrated electromyogram in the monitoring group were higher after two months of training compared to control group. ${ }^{10}$

\section{Role of Trunk in Postural Control}

The human body consists of body segment that built from a collective of joint which was interconnected to each other by soft tissue such as muscle to manage a motion. One can say the human body is a kinetic chain which centered in the middle region called the trunk. This kinetic chain is the underlying system of human movement. As the trunk being the focal point of the body, it will assume a significant work in keeping up the body posture by setting up the body for the action of the limbs against gravity. ${ }^{11,12}$ The ability to maintain proximal trunk control is a must for an individual to stay balanced while implementing any functional activities. ${ }^{13}$ The normal trunk function will maintain an upright trunk position to support limbs movement, reduce risk of falls, prevent contracture and deformities of the spine, improved the potential to interact with environmental surroundings, maintain functions of visions, maintain feeding and swallowing functions, increase capability in everyday activities and other relevant tasks. ${ }^{14}$

For years, trunk control is recognized as having predictive value on comprehensive activity of daily living outcome after stroke. ${ }^{13}$ This is the rationalization of why acquiring control of the trunk at an early stage has been a crucial point of the stroke rehabilitation program. ${ }^{14}$ Various randomized controlled trials that concentrated on trunk improvement had proven preferred result compared to control groups among stroke survivors. ${ }^{15}$

Trunk control is an essential part of postural control. Postural control is fundamental element that will adjust body's position in space to serve two main objectives of orientation and stability. Postural orientation is characterized as the ability to sustain a proper connection between the body portion and between the body and the environment for a specific task. Postural stability is the ability to control the center of mass $(\mathrm{COM})$ in correlation to the base of support (BOS). Every functional task demands postural control. This means each functional task has an orientation component and a stability component. These components are never alike and it will vary according to the task and environment. ${ }^{16-17}$

The postural control system emerges from an intricate reciprocal action of musculoskeletal and neural network systems. Components of 
musculoskeletal system included are joint range of motion, flexibility of the spine, muscle properties, and biomechanical connection between linked body portions. Component of neural system necessary to postural control are motor processes, sensory processes and higherlevel cognitive processes. Motor processes imply regulating muscles throughout the body into muscle synergies. Sensory processes consist of both individual sensory systems such as the visual, vestibular, and somatosensory systems, in combination with the process of sensory organization. Last yet not the least is higher-level cognitive processes that including both cognitive resources and strategies vital for mapping sensation to action and assuring anticipatory and adaptive aspects of postural control. ${ }^{17}$

Postural Control during Activity of Daily Living Activities of daily living (ADL) are everyday activities, mostly home-based activities that individuals accomplished to preserve their health and well-being. ADL comprise of basic and instrumental ADL. The main activities of basic ADL are self-care such as bathing, dressing, eating, grooming, use of the toilet, and mobility within the home. There is also ADL that go beyond basic functional task known as instrumental ADL or extended ADL. According to Lawton, these activities are housekeeping, food preparation, laundry, shopping, use of telephone, use of transportation, use of medication, and financial management. For individuals to attend their daily self-care is mandatory for constructing a sense of identity along with obtaining acceptance in a social world. ${ }^{18,19}$

The time proportions for individual to perform ADLs are $30 \%$ of typical individual's waking hours with the main executor for these activities are the limbs. The upper limb will do any task such as reaching, lifting, holding or any other functional task, while the lower limb will help transfer and ambulation activities, starts from standing, walking until running. Proper postural control is a requirement for all these activities to be fulfilled. ${ }^{19-21}$

For examples, in simple activity such as holding a glass full of water will result in posture asymmetry that causes body perturbation. This external perturbation will impair balance and needs to be restoring immediately by activating central nervous system. Then the central nervous system will activate trunk and lower limb to regain balance. This postural adjustment will prevent someone from falling down. ${ }^{22}$

Postural adjustment to control balance composed of anticipatory postural adjustment (APA) and compensatory postural adjustment (CPA). Anticipatory postural adjustment sets up the position of the center of mass by activating the trunk and lower limb muscles in advanced to an expected body perturbation while decreasing the danger of overlook stability. Compensatory postural adjustments are commenced based on sensory feedback and act as a mechanism to replace the center of mass position after a perturbation has already happened. If a balance is needed to be restored, the combination of APAs and CPAs are generated depending on the task demand. When the mechanism of APAs is not propagated, the neural system is using CPAs to regain balance and vice versa. ${ }^{22}$

Human postural control depends on the combined use of anticipatory and compensatory postural mechanisms. For illustration, whenever someone is having unpredicted perturbation to posture 
such as tripped over a stone while walking, the mechanism used is CPAs to maintain stability and prevent falls down. Conversely, if the perturbation is anticipated, APAs serve as a mechanism to prepare the body for the imminent disturbance and are subsequently followed by CPAs that aid in finalizing the process of balance restoration. As such, the exertion of APAs considerably turn down the necessity for extensive CPAs and results in significant improvement in postural balance as exhibited by considerably smaller shifts of the body's center of mass. ${ }^{23}$

The APA and CPA are generated by central nervous system through activation of musculoskeletal system. The two main patterns are reciprocal activation and co-contraction. Activation of the anterior and posterior muscle sequentially occurs in reciprocal activation while co-contraction of muscle will increase joint stiffness to provide better body stability. Reciprocal activation of muscles is assumed as a strategy of efficient energy saving to deliver upright posture and also used whenever postural control is disrupted by minor stability, while co-contraction is a strategy of postural control which is preferred in conditions with major body instability. ${ }^{22}$

\section{Stroke Impact on Postural Control}

Stroke is a sudden disruption of brain vasculature, which results in neurological deficits. Strokes are classified into two main etiologies which is ischemic that usually caused by a vascular blockage, and hemorrhagic that caused by bleeding within the brain tissue. The most common symptom of a stroke is focal weakness or hemiparesis, even though stroke can produce a wide range of symptoms such as sensory loss, speech and language disturbance, visual loss, etc. ${ }^{2}$
Hemiparesis described as total or partial loss of muscular strength or paralysis affecting either side of the body after a stroke. This symptom was reported up to $65 \%$ of stroke patient. ${ }^{24}$ Hemiplegia as the utmost stand out symptoms not only affect in limb activity but also has it effects on trunk muscle function both sides of the body affecting the proximal stabilization that eventually will influence the mobility of the distal part. ${ }^{25,27}$

The trunk dysfunction in post stroke patient has been demonstrated in many studies. It is known that trunk musculature that build up postural stabilization received input from bilateral hemispheric, but still the effect of upper motor neuron lesion on functional changes in trunk control is noticeable. ${ }^{28}$ The symptoms reported are muscle paralysis and hindered activity of the trunk muscles, obvious trunk position sense inaccuracy, deficiency center of pressure control when sitting, reduced trunk performance, and trunk dissymmetry during walking. ${ }^{15}$

The evidence comes from a study by Dickstein and colleagues that recorded specific trunk muscles during anticipatory postural adjustment through electromyography activities in stroke patient with hemiparesis. The researcher put the recording electrodes at the the latissimus dorsi muscles and lumbar erector spinae bilaterally while the subject flex both of their arm. The recording electrodes also being put in the rectus abdominis muscles and the obliquus externus muscles bilaterally while the subject flex their hip at the same time. The abnormalities activity of trunk muscles in the hemiparetic subjects were noted by the researcher. The apparent abnormalities were reduced lateral trunk muscles activity level, delayed onset of muscle activity, and diminished coordination between activation 
of relevant muscular pairs. They also noticed that the abnormalities were correlated with motoric and functional deficits. ${ }^{14,28}$

Another study also focused on trunk muscle strength impairment after stroke is conducted by Bohannon, Cassidy, and Walsh. Their study comprises of the same amount of participants in both hemiparetic secondary to stroke group and control group. The strength of trunk muscles was assessed by hand held dynamometry specifically in forward and lateral trunk flexion direction. It was done while participants were sitting up straight throughout the study. The outcome revealed that trunk muscle strength was remarkably reduced in the participants in proportion to controls; with the biggest strength discrepancy was in forward flexion strength. The subject showed trunk weakness on the paretic side compared to the nonparetic side. The conclusion of the study noted that impaired in trunk muscle strength of stroke patients occurred in multi directionally. Bohannon also studied the impact of trunk muscle strength on sitting stability and mobilization. The outcome exhibit that the mean force of trunk lateral flexion on the paretic side was distinctly less, compare to the mean force of trunk lateral flexion on the nonparetic side. The study also revealed a statistically strong association between strength and sitting stabilization of the lateral trunk flexors. ${ }^{14}$

Not only in the motoric system, the trunk abnormalities also seen in the sensory system. Ryerson and colleagues disclosed impairments of trunk position sense in hemiparetic post stroke subject. These subjects displayed obvious trunk repositioning error than age-matched controls. Based on this result, the authors proposed retraining of trunk position sense especially on sagittal and transverse movements as a potential intervention strategy in post-stroke cases to improve trunk control and balance. ${ }^{14}$

In healthy individual, the movements of the upper and lower limb are preceded by the activation of trunk musculature to control postural stabilization. This is not the case in stroke patient population. In stroke subject, the muscles of moving limb are triggered earlier compared to the trunk muscle because the activation of the trunk muscles is hampered. In an examination to check the proprioceptive position sense test of the trunk, stroke subjects expressed an incompetence to reposition from the initial posture in sagittal, frontal and horizontal planes compared to healthy people. ${ }^{29}$

Additional problem also seen in stroke posture is postural malalignment. Prolonged postural malalignment will have the consequences of muscle shortening on one side of the trunk and muscle over-stretching on the counterpart side. One simple illustration is in a case of posterior pelvic tilt with lumbar flexion that will result in shortening of the anterior musculature and elongating (overstretching) of the posterior muscles. Similar problems will also come up when an individual performing trunk lateral flexion on the right side which will end up in muscle shortening on that side and elongating on the counterpart side or the left side of the trunk. Unilateral weakness is the cause that held responsible for this problem to occur. Any other cause such as imbalanced skeletal muscle contraction, perceptual deficits and an inability to apprehend midline and soft-tissue tightness will also heightened the problem. If this postural malalignment is left untreated, it will have several consequences such as loss of range of motion, and an inadequacy to develop optimal exertion to activate the muscle group in question. ${ }^{14}$ 
Postural performance in stroke patients can be identified through several clinical tools. A systematic review was conducted to determine which clinical tools are superior in assessing the obscured postural problems. At present, the available tests which particularly evaluate postural performance in stroke subject are the Trunk Control Test and Trunk Impairment Scales. The Trunk Control Test is a well-accepted assessment tool, but also has some limiting aspect according to literature. This test does not take into consideration the quality of movements and its ceiling effect. Another test is then developed to resolve these short comings which were known as the Trunk Impairment Scale. The Trunk Impairment Scale uses a standardized sitting position throughout the assessment whilst performing the motion in sagittal, frontal and horizontal plane. Trunk Impairment Scale also takes into account the quality of movement, whether the assignment is performed with compensations technique or not. Some studies mention that there is no ceiling effect on Trunk Impairment Scale. A study by Fujiwara $\mathrm{T}$ et al. on the psychometric property of Trunk Impairment Scale reported that, Trunk Impairment Scale was an applicable adjunct with good validity and reliability in stroke outcome research. Hence, Trunk Impairment Scale was chosen for assessment of trunk performance of stroke patients in this study. ${ }^{30}$

Hemiparetic patients with poor trunk (postural) function at hospital admission stayed longer in a rehabilitation ward compared to patients who had better initial trunk function and could walk longer distances with speed at discharge. Moreover, not only the assessment of trunk performance in sitting position but also by checking postural balance in lying and standing can predict poststroke functional ability and discharge destination planning for inward patient rehabilitation. Ambulation competency if done independently at discharge had a significant correlation to early unsupported sitting balance and also found that this ability could predict independent ambulatory status in the later stage of stroke recovery. Trunk Impairment Scale and its static sitting balance subscale were considered as the most critical predictors of Barthel Index score at six months after stroke. By considering this, it is very important to measure total Trunk Impairment Scale and its static sitting balance subscale at admission and functional ability measured at discharge from the rehabilitation center. ${ }^{25}$

\section{Postural Control Rehabilitation Principles}

The recovery process of trunk control as a component of postural control varied over time. Significant trunk performance improvement will be mostly seen at first month after the onset of stroke. The temporal profile of the trunk control restoration resemble to the recovery of upper limb, lower limb, and functional ability. ${ }^{14}$

Trunk rehabilitation in stroke patient is based on improving postural control which is essentially needed in operating everyday functional activity. Postural control consists of stabilizing one important part of human body which is "core". The "core" is equal to a box, with abdominal muscles in the front, para spinal and gluteal muscles in the back, the diaphragm as the roof, and the pelvic floor and hip girdle musculature as the bottom. The structures that built up the core divided into of passive and active component. The passive components are thoracolumbar spine and pelvis; meanwhile the active components are the trunk musculature. The combination of core structures will provide core stability which defines as the ability to stabilize the spine as a 
result of local muscle activity. This core stability has a high established reliability concerning improving the trunk muscle performance. Core stability delivers a significant part in upgrading function and alleviating weight bearing at the joints whilst doing various assignments..$^{31-35}$

The core, which lies in lumbar area, needs to be sturdy the whole time as its function to hold the lumbar area stable and at the same time letting the limbs moving freely. Both passive and active component of the core are working simultaneously. If one or both components are disrupted in its function, then the stability began to be compromised. It has been discovered that the active component which is musculature is the key part in sustaining core stability under different circumstances. Panjabi concluded that attaining muscle activity is used to recompense for a loss or decrease passive stability. Muscle activation contributes to trunk stability through co-contraction mechanism. Normal individuals enhance co-contraction mechanism as a reaction to situations that interrupt core stability. This mechanism is set off by specific stimulation that comes from both mechanoreceptors and nociceptors. Co-contraction then linked the stability of the upper and lower limbs via the abdominal fascial system. To obtain this mechanism of co-contraction, specific neural input and output are required. ${ }^{34}$

Cholewicki and Van Vliet reported that all trunk muscles shared similar responsibility to core stability. The contributions proportion of each muscle group constantly alters throughout any purposeful activities. The abdominals are the vital element of the core. Specifically, the work is mostly done by the transversus abdominis muscle. Activating the transversus abdominis elevates intra-abdominal pressure and tension the thoracolumbar fascia. Fascia of the thoracolumbar is an indispensable feature in connecting the lower limbs to the upper limbs. It helps to make a 'hoop' or circular band around the abdomen, which formed by the fascia in the posterior aspect, abdominal fascia in the anterior aspect and the oblique muscles in the lateral aspect. This circular band comes out as strong that it will generate stabilizing corset effect. Elevation of intra-abdominal pressure by the core muscle contraction occurs prior to initiation of large segment movement of the limbs. Therefore, the spine is secured in advanced to limb motion, hence permitting the limbs to own a steady foundation for movement and muscle activation. It is important that the lumbar spine formed a rigid cylinder to augment stiffness of the lumbar spine by core muscle contraction. Another principal aspect to note is that the oblique abdominal and rectus abdominis muscles are behaved in direction-specific patterns with regards to limb motion. This pattern will help preserve proper body mechanics of any movement in time. ${ }^{34}$

Concisely, the core works as the central point of the functional kinetic chain. The core also being mention as the "powerhouse" which means the foundation or engine of all limb movement. ${ }^{33,34}$

By knowing the core role in providing safe and efficient of any human movement, exercises to improve core-stability become principal to set out. When core stability exercise is prescribed as a treatment, this should contain of simultaneously activating the deep trunk muscle with the aim of achieving head, neck and body stability prior to limb movement and throughout the movements. The process of regaining postural stability by retraining the "core" will improve 
the competency of performing everyday activity which is decreased due to stroke. Thus, effective programs which included core stability exercise must be developed for enhancing the quality of life in stroke population..$^{31,32}$

\section{CONCLUSION}

Postural control as an integral part on human movement is affected by stroke. Reducing in postural control as proximal stabilizer will diminish the ability to execute limbs movement. Because postural control becomes one of the predictor of stroke functional outcome, the prompt and precise assessment and management should be carry out at early stage after stroke. Rehabilitation to enhance postural control must include core stability training which is shown effective in improving functional activities that in turn increased the quality of the life of the stroke patients.

\section{REFERENCES}

1. Johnson W, Onuma O, Owolabi M, Sachdev S. Stroke: a global response is needed. Bull World Health Organ. 2016;94:634-A. (Online Source Download 22 May 2020)

Available from https://www.who.int/bulletin/ volumes/94/9/16-181636.pdf

2. Stein J, Brandstater ME. Stroke Rehabilitation. In: DeLisa's Physical Medicine \& Rehabilitation Principles and Practice. 5th ed. Wolters Kluwer Lippincott Williams \& Wilkins; 2010 : 551-74.

3. The GBD 2016 Lifetime Risk of Stroke Collaborators. Global, regional, and countryspesific lifetime risk of stroke, 1990 and 2016.
N Engl J Med. 2018; 379: 2429-37.

4. Kementerian Kesehatan Republik Indonesia. $2018: 165$.

5. Donkor ES. Stroke in the 21st century: A snapshot of the burden, epidemiology, and quality of life. Stroke Res Treat. 2018 : 1-10.

6. Vowell MP. Function and movement of the trunk and neck. In: Kinesiology for the Occupational Therapy Assisstant, Essential Component of Function and Movement. 2nd ed. Slack Incorporated; 2018 : 101-25.

7. Liao CF, Liaw LJ, Wang RY, Su FC, Hsu AR. Relationship between trunk stability during voluntary limb and trunk movement and clinical measurement of patient with chronic stroke. J Phys Ther Sci. 2015; 27(7): 2201-6.

8. Park HJ, Oh DW, Kim SY. Effects of integrating hip movement into bridge exercise on electromyographic activities of selected trunk muscles in healthy individuals. Man Ther. 2014; 19(3): 246-51.

9. Bae DY, Kim SY, Park SR, Oh JS. Effect of non-paretic arm movement during bridge exercise on trunk muscle activity in stroke patients. J Phys Ther Sci. 2019; 31(4): 291-4.

10. Zheng Y, Ke S, Lin C, Li X, Liu C, Wu Y, et al. Effect of sore stability training monitored by rehabilitative ultrasound image and surface electromyogram in local core muscles of healthy people. Pain Res Manag. 2019: 1-8.

11. Pathak S, Kumar KV, Nayak A, Kedambadi RC. The relationshio between pelvic alignment and trunk control in stroke subjects: a cross-sectional study. Int J Res Med Sci. 2014; 2(4): 1483-7.

12. Sciascia A, Cromwell R. Kinetic chain rehabilitation: a theoretical framework. Rehabil Res Pract. 2012; 2012: 1-9.

13. Kartikhabu S, Rao BK, Manikandan N, Solomon JM, Chakrapani M, NayakA. Role of 
trunk rehabilitation on trunk control, balance, and gait in patient with chronic stroke: a prepost design. Neurosci Med. 2011; 2: 61-7.

14. Gillen G. Trunk control : supporting functional independence. In: Stroke Rehabilitation A Function-Based Approach. 4th ed. Elsevier Inc. 2016: 360-93.

15. Haruyama K, Kawakami M, Otsuka T. Effect of core stability training on trunk function, standing balance, and mobility in stroke patients: a randomized controlled trial. Neurorehabil Neural Repair. 2017; 31(3): 240-9.

16. Gjelsvik BEB, Strand LI, Naess H, Hofstad $\mathrm{H}$, StureSkouen J, Eide G, et al. Trunk control and lesion locations according to Alberta Stroke Program early CT scan in acute stroke: a cross-sectional Study. Int J Phys Med Rehabil. 2014; S3: 001

17. Shumway-Cook A, Woollacott MH. Normal Postural Control. In: Motor Control, Translating Research into Clinical Practice. 5th ed. Wolters Kluwer; 2017 : 444-528.

18. Legg LA, Lewis SR, Schofield-Robinson OJ, Drummond A, Langhorne P. Occupational therapy for adults with problems in activities of daily living after stroke (review). In: Cochrane Database of Systemic Review. John Wiley \& Sons, Ltd. 2017: 1-19.

19. Christiansen $\mathrm{CH}$, Rogers SL, Haertl KL. Functional evaluation and management of self-care and other activities of daily living. In: DeLisa's Physical Medicine \& Rehabilitation Principles and Practice. 5th ed. Wolters Kluwer Lippincott Williams \& Wilkins; 2010 : 243-88.

20. Song BK. The effect of upper extremity training with a focus on functional reaching, on trunk control and ADL performance in post-stroke hemiplegic patients. J Kor Soc
Phys Ther. 2011; 23(3): 71-7.

21. Van Criekinge T, Saeys W, Hallemans A, Vereeck L, De Hertogh W, Van de Walle P, et al. Effectiveness of additional trunk exercises on gait performance: study protocol for a randomized controlled trial. Trials. 2017; 18 (249): 1-12.

22. Chen B, Lee YJ, Aruin AS. Anticipatory and compensatory postural adjustment in conditions of body asymmetry induced by holding an object. Exp Brain Res. 2015; 233(11): 3087-96.

23. Aruin AS. Enhancing anticipatory postural adjustments: a novel approach to balance rehabilitation. J Nov Physiother. 2016; 6(2): 1-5.

24. Bindawas SM, Mawajdeh HM, Vennu VS, Alhaidary HM. Functional recovery differences after stroke rehabilitation in patients with uni- or bilateral hemiparesis. Neurosci. 2017; 22(3): 186-91.

25. Kartikhabu S, Chakrapani M, Ganeshan S, Rakshith KC, Nafeez S, Prem V.A review on assessment and treatment of the trunk in stroke. Neural Regen Res. 2012; 7(25): 19747.

26. Chiang SL, Lin $\mathrm{CH}$, Lin $\mathrm{CH}$, Lu LH, Chang ST, Sung WH, et al. Analysis of trunk rolling performances by mattress mobility detection system in post stroke patient: a pilot study. Biomed Res Int. 2016: 1-9

27. Lim CG. Effects of trunk control robot training on balance and gait abilities in persons with chronic stroke. Phys Ther Rehabil Sci. 2020; 9(2):105-12.

28. Liao CF, Liaw LJ, Wang RY, Su FC, Hsu AR. Electromyography of symmetrical trunk movements and trunk position sense in chronic stroke patients. J Phys Ther Sci. 2015; 27(9): 2675-81. 
29. An SH, Park DS. The effects of trunk exercise on mobility, balance and trunk control of stroke patients. J Korean Soc Phys Med. 2017; 12(1): 25-33.

30. Desai M, Gawde S, Prabhu S. A study of the relationship between trunk impairment and gait in patient with a cerebrovascular accident. Int J Health Sci Res. 2018; 8(10): 113-23.

31. El-Nashar H, ElWishy A, Helmy H, ElRwainy R. Do Core Stability exercises improve upper limb function in chronic stroke patients. Egypt J Neurol Psychiatr Neurosurg. 2019; 55(38): 1-9.

32. Yu SH, Park SD. The effects of core stability strength exercise on muscle activity and trunk impairment scale in stroke patients. J Exerc Rehabil. 2013; 9(3): 362-7.

33. Chung EJ, Kim JH, Lee BH. The effects of core stabilization exercise on dynamic balance and gait function in stroke patients. $\mathrm{J}$ Phys Sci. 2013; 25: 803-6.

34. Borghuis J, Hof At L, Lemmink KAPM. The importance of sensory motor control in providing core stability. Sports Med. 2008; 38(11): 893-916.

35. De Luca A, Squeri V, Barone LM, Mansin HV, Ricci S, Pisu I, et al. Dynamic stability and trunk control improvements following robotic balance and core stability training in chronic stroke survivors: a pilot study. Front Neurol. 2020; 11(494): 1-18. 